\title{
Messianic expectations in the Old Testament
}

\author{
Wolter Rose \\ Department \\ Biblical Studies and Languages \\ University of Kampen \\ The Netherlands \\ E-mail: whrose@tukampen.nl
}

\section{Abstract}

\section{Messianic expectations in the Old Testament}

The New Testament is connected to the Old Testament in a number of different ways. It is not unusual to find the word "messianic" used to categorise all the different ways in which the writers of the New Testament find Christ (and, similarly, Jewish sources of the Second Temple Period later find the future Messiah) in the Old Testament, or to identify the specific passages in the Old Testament which are now seen to point to Christ/the Messiah. In this article I argue that, if one wants to be able to appreciate the diversity, one should abandon this indiscriminate use of the word "messianic". After a brief discussion of the meaning and use of the Hebrew word משיח in the Old Testament, I propose a definition of the phrase "messianic expectations" (expectations focusing on a future royal figure sent by God someone who will bring salvation to God's people and the world and establish a kingdom characterised by features such as peace and justice). Subsequently, the origin of these expectations is located as in the proclamation of the eighth-century prophets (Amos, Isaiah and Micah). Finally, one special category of messianic expectations, that is, messianic expectations in the Books of the Psalms, is dealt with.

\section{Introduction}

The subject "messianic expectations in the Old Testament" is focused on in this article from the viewpoint of a Christian. In the New Testament one finds answers to a great diversity of questions relating to the person and the life of Jesus Christ. The way in which the writers of the New Testament answer questions like "Who is Jesus Christ?", and "What did he come to do?", shed fresh light on the Old Testament. These new views of the Old Testament have met with opposing reactions from the 
very first beginning. Even after 2000 years one observes that this new way of reading the Old Testament is still controversial. ${ }^{1}$

Suppose that I intended to write a book titled The Veil Removed: The Old Testament seen in the light of Jesus Christ and that this article would be one of the chapters. Consequently that chapter about "messianic expectations in the Old Testament" would be just one in a range of subjects we have to deal with when we aim to study the fresh light that Jesus Christ sheds on the Old Testament.

Other possible subjects could also be included as chapters in the suggested book The Old Testament seen in the light of Jesus Christ (the list is far from exhaustive). ${ }^{2}$

- There could be a chapter on typology, the phenomenon that there is something characteristic to the way God acts. God has his own style. In retrospect when we look back from the New Testament specific persons, objects and certain events in the Old Testament can now be seen to point to something in which we are able to trace and recognise something of Jesus or the way in which he acts. In this respect one could think of the ladder which Jacob saw in a dream the ladder on which the angels of God ascended and descended (Gen. 28:12), and Jesus' reference to this dream when he says (John 1:51) "you shall see heaven open, and the angels of God ascending and descending on the Son of Man".

- Another possible chapter could be dedicated to "Jesus takes the place of the people of Israel". In such a chapter the words "out of Egypt I called my son" in Hos. 1:11 would be discussed. In this verse the name "my son" refers to Israel as the people of God. As is wellknown, Matthew quotes these words (Matt. 2:15), but applies them to Jesus, presumably as the son of God. The phenomenon that the concept of the people of Israel is concentrated in one person who eventually takes the place of the people, can already be witnessed in the Old Testament itself. In the passages dealing with the "Servant of the LORD" in Isa. 42, 49 and 53, e.g., the call to be the Servant is first issued to the people of Israel (Isa. 42:1-4), but when they are shown to be unable to perform that task, the prophet is called to be the

1 As can be seen from the diverging approaches to be found in Struppe, 1989; Van Groningen, 1990; Dassmann \& Stemberger, 1993; Knevel \& Paul, 1995; Satterthwaite et al., 1995; Laato, 1997; Day, 1998; Horbury, 1998.

2 For a similar approach, see Greidanus (1999), who distinguishes six ways: Redemptive-Historical Progression, Promise-Fulfilment, Typology, Analogy, Longitudinal Themes, Contrast. 
Servant (Isa. 49:1-6). The prophet also realises that that calling goes beyond his capabilities; he then draws a picture of an unidentified person who takes the place of the people and by his suffering takes away the guilt of the people (Isa. 52:13-53:12. For this line of interpretation of these passages, see Goldingay, 1984:80.152-59; and Williamson, 1998:113-66).

It would be possible to label all the above-mentioned subjects in the suggested book, The Old Testament seen in the light of Jesus Christ, as "messianic". That would indicate that the words "messiah" or "messianic" are used in a broad sense. My approach will be to utilise the meaning implications of these words in a more restricted and specific sense. ${ }^{3}$ There are several reasons why this approach should be followed.

- First, it is wrong to assume that the way in which words like "messiah" or "messianic" are commonly used today, that is, as referring to a future, possibly eschatological, saviour figure, is similar to the way the word "messiah" had normally been used in the Old Testament. I thus want to avoid the impression that these words - in the sense we use them today - played a prominent role in Old Testament times.

- Second, the New Testament is connected to the Old Testament in various ways, and one runs the risk of making it difficult to appreciate that diversity when one uses one word, "messianic" for all those different connections.

In this article I will explore the subject of messianic expectations in the Old Testament in four sections. First, the meaning and use of the Hebrew word משיח will discussed; second, a definition of "messianic expectations in the Old Testament" will be given; third, the origins of messianic expectations in the Old Testament will be traced, and finally one special category of messianic expectations will be dealt with messianic expectations in the Books of the Psalms.

\section{The meaning and use of the word משיח in the Old Testament}

The word "messiah" and its equivalent in modern languages is derived from the Hebrew word משיח. I will now first explore what this word meant and how it was used in the Old Testament. As earlier stated it is wrong to assume that the way in which words like "messiah" or "messianic" are commonly used today is similar to the way the word "messiah" was

3 For examples of the use of the words "messiah" and "Messianic" in a broad sense, see Van Groningen (1990) and Peels (1999a:11.28-30). 
normally used in the Old Testament. In this section I want to develop this line of thought.

The word משיש is derived from the root משח , which as a verb points to the meaning of "to rub with oil, anoint". The verb משח is used with respect to both objects and persons. The nominal form משיח is used as an adjective, "anointed", and as a noun "anointed one". Persons of whom it can be said that they are "anointed (ones)" are either priests, prophets, or kings. The act of anointing symbolised that God commissioned that individual for a specific task. 4

When the word משיח is used with respect to a priest, then in most cases the word is used not on its own, but as a complement to a noun, either as an adjective or in apposition, "the anointed priest" or "the priest, the anointed one". One finds this word four times in the singular (in Lev. $4: 3.5 .16 ; 6: 15$ ), and once in the plural (in Num. 3:3). The use of the noun with respect to prophets is limited to just a few cases in which the noun in the plural is found parallel to the plural of נביא, "prophets", where both nouns refer to the people of God (Ps. 105:15 = 1 Chr. 16:22).

משיח used of a king is found predominantly in 1-2 Samuel and occasionally in the prophetic books, and in almost all cases it refers to the present king of that moment in history (that is, not to a future king). 5 It is important to take a closer look at the grammatical construction in which מששיח is found when used to refer to the present king. In these instances one usually finds the noun not standing on its own, but in a compound phrase משיח יהוה, "the anointed of the LORD" (once, "the anointed of the God of Jacob") or in an abbreviated form, with a suffix replacing the divine name, e.g. משיחו, "his anointed".

While in these mentioned cases in 1-2 Samuel and in the prophetic books the referent of the word "anointed (one)" was usually a contemporary figure, usually a hoped for king, in subsequent times the typical Old Testament reference of the word implied a future figure (see for instance the reference in the Old Testament, in Dan. 9:25-26; in this instance, however, unlike the later texts, the word is used without an article). Out of this latter use a special use developed, in which the word was used in a different grammatical construction: it could from now on also stand on its own, that is, without the complement of a divine name

4 On the function of the act of anointing see Viberg (1992:89-119).

5 The obvious exceptions are 1 Sam. 2:10 and Hab. 3:13, and if (without article!) in Dan. 9:25-26 refers to a royal figure (which is not clear), one would have to add these two cases as well. 
or a suffix, but preceded by the article: "the messiah". This is how one finds the word in early Jewish writings, for example in the Dead Sea Scrolls. Its Greek equivalent is found in the New Testament (ho messias in John $1: 41 ; 4: 25$, the Hebrew word in Greek characters, explained by the Greek word christos "Christ"). And this is also how the word is used in most cases in modern discussions.

\section{A definition}

It is not an easy task to give a definition of the phrase "messianic expectations in the Old Testament". After the survey of the meaning and use of the Hebrew משיח in the Old Testament, it is not difficult to see why a definition presents such a problem. The most important reason for the difficulties surrounding a definition of the phrase "messianic expectations in the Old Testament" is the fact that when one talks about expectations, one looks by definition into the future. But, as we have just seen, in the Old Testament משיח usually refers not to a future king, someone whom one could set one's hopes and expectations on, but to a present king. This state of affairs makes every definition of the phrase "messianic expectations in the Old Testament" 6 somewhat provisional, and this will also apply to the definition I will suggest.

In this article, I will use the phrase "messianic expectations" to refer to expectations focusing on a future royal figure sent by God who will bring salvation to God's people and the world and establish a kingdom characterised by features such as peace and justice. The phrase "the messiah" is used to refer to the figure at the heart of these expectations. It should be noted that the way I use these phrases in this article is guided by an interpretation of the texts as they were intended and meant to be understood within the perspective of the first audience of narrators, poets or prophets (as far as one can locate them in time and space). The perspective of later audiences, including Jewish or Christian ones, who have found reasons to interpret a particular passage as pointing to the "messiah" is not the focus of the interpretation as used in this article. A few comments will probably clarify the specific definition I have proposed.

\section{- Word and concept}

Some scholars have pointed to the almost complete absence in the Old Testament of the use of the word משיש for a future king, and concluded that is not appropriate to speak about "the messiah" (in its technical 1978, see Cazelles (1978:217-24). 
sense, referring to a future royal figure) in the Old Testament, or about "messianic expectations in the Old Testament". I consider this conclusion to be based on a mistake, in which two things are confused: the presence of a particular complex of ideas, and the presence of one specific word to refer to that complex of ideas or to its core. In my view, it is perfectly legitimate to speak about "messianic expectations in the Old Testament", even when the word משיח in the Old Testament is not yet used in its technical use for a future royal figure (Van der Woude, 1985: 95 note 42 ).

\section{- Forward-looking orientation}

In the introduction of this article I have clarified why I prefer to use words like "messiah" and "messianic" in a restricted sense. This preference implies that my approach will be different from those who will label everything which in one way or another can be related to Jesus Christ as "messianic". There are, however, some observations which scholars who have taken this approach have made, which I am happy to endorse. First, they point to a forward-looking orientation which can be found in the Old Testament from the very first beginning. ${ }^{7}$ This forward-looking orientation is founded in promises which God has given, and which deal with what will happen in future, or with what he will do in future. In this respect one can think of promises like the one in Gen. 3:15, or the promises made to Abraham in which a key role in mediating God's blessing is given to one particular family line, the descendants of Abraham.

\section{- Kings and rulers}

Second, this approach rightly points to the fact that themes like rule or kingship have already been part of these promises in an early phase, either in the more general form with kings in the plural, like "kings will come from you" (said to Abraham in Gen. 17:6.16 and to Jacob in Gen. $35: 11$ ), or related to one particular person as a representative of a tribe, in respect to whom royal attributes like sceptre and staff are mentioned (Gen. 49:10-11). One can also mention Num. 24:17-19, a prophecy of the pagan prophet Balaam, in which the prophet uses the imagery of a rising star to pledge to Jacob/lsrael a ruler's position which will result in the submission of neighbouring enemy nations.

7 In another context Peels calls this the "persistent future orientation of the proclamation of the Old Testament" (Peels, 1999b:38, note 10). 
Whether one may call these promises about kings "messianic expectations" or not is a matter of debate. ${ }^{8}$ Some scholars will confirm that one can indeed, and underline that traditionally these promises have been interpreted as messianic. Such a tradition goes as far back as early Jewish exegesis, which is first attested in ancient translations of the Old Testament, like the Greek Septuagint and the Aramaic Targums. It is interesting that such a clear messianic interpretation is not found in the New Testament.

Other scholars prefer not to label these promises as "messianic expectations". I am inclined to agree with this. Though these promises are similar to "messianic expectations" in the prophetic books in that they deal with future kingship, they are different in some important aspects. The passages from Genesis and Numbers are about kingship as such without much qualification, while in the prophetic books the subject is not so much kingship as such, but one individual king, whose rule is marked by certain characteristics like peace and justice. ${ }^{9}$ There is another reason why I would not group these promises from Genesis and Numbers with "messianic expectations". If one tries to establish the original reference of these passages, it seems more plausible to interpret them as pointing forward to the kingship and the dynasty of David (compare 1 Chron. 5:1-2). However, what is striking about messianic expectations in the Old Testament is the fact that they multiplied a few centuries after David, long after these promises dealing with kingship in Genesis and Numbers had found their fulfilment in the kingship of David and his house.

\section{- Hannah's song}

For the same reason I find it difficult to consider the end of Hannah's song (2 Sam. 1:10) as belonging to the so-called messianic expectations. The figure called "his [i.e., YHWH's] anointed" is clearly a future figure, ${ }^{10}$ which makes this an unique case in the books of Samuel, where refers to the present king, Saul or David, not a future king. But also in this case one has to find the fulfilment in the kingship of David (compare Goslinga, 1968:101-102), an interpretation which can be made

8 Compare Peels (1999a:30), who uses the word "controversial" to describe the question whether these passages from the Pentateuch contain Messianic expectations.

9 Schibler (1995:89): “This hope relates particularly to the practice of משפט ('justice') and צדקה (righteousness)"; compare Weinfeld (1995:57-67).

10 The more so when one allows for the possibility that Hannah did not make a new song but used a song which already existed (see Lettinga, 1980:93, reprint in Lettinga 1998: 38). 
plausible on the basis of the way the books of Samuel ends. The two psalms in the last two chapters of 2 Samuel (2 Sam. 22:2-15; 23:1-7) refer back to Hannah's song in the beginning of 1 Samuel, and this is done in such a way that the writer makes it clear to his readers that David is the one who has fulfilled the expectations expressed in Hannah's song (VanGemeren, 1988:216).

\section{- The dynastic oracle in 2 Samuel 7}

Dealing with the two books of Samuel there is another passage with which one must interact when one explores the subject of "messianic expectations in the Old Testament": the prophecy given by Nathan in 2 Sam. 7:1-17. After a promising start with king Saul and the deplorable outcome of his kingship, David is now established as king on the throne in Jerusalem. He has subjected all his enemies, and one can speak of a situation of "rest" for the king and his people. The king has built himself a palace and now develops the plan to build a temple for YHWH. Nathan the prophet endorses the plan of the king, but the next day he is summoned by the LORD to go to the king to deliver a message from the LORD. In that message the roles are reversed in a sense. It will not be the king who will build a house for the LORD: the LORD will build a house for the king. This is then developed in a sweeping promise for the king. The LORD pledges himself to provide a dynasty, which is said no less than three times to endure "for ever". The LORD declares to be true to the promise even when David's successors would fail to stand up to their calling.

It is important to notice that mention is made here of a line of successors, not about one individual successor in particular. That is why in my opinion one should not count this promise with the "messianic expectations in the Old Testament". This, however, is a very important promise for our discussion of "messianic expectations in the Old Testament", because it is - as we shall see - the seedbed from which all messianic expectations could grow, even though one cannot call the oracle itself properly messianic. 11

\section{Tracing the origins of messianic expectations in the Old Testament}

When the origins of "messianic expectations in the Old Testament" are explored the question I will deal with concerns the following issue: is it possible to point to one particular period in the history described in the

11 Compare Westermann (1964:215-17): “the 'Messianic' promises proper [...] are all based on the prophet Nathan's oracle of promise for the Davidic royal house (II Sam. 7)" (reprint in Westermann, 1974:241-43); Van der Woude, 1985:99-100; Peels, 1995: 46-47. 
Old Testament and say this is the time in which messianic expectations emerged for the first time? Once again, different answers are given to this question. Some people would answer the question in the negative because in their view it is only in the intertestamental period that one can for the first time speak of messianic expectations. In the section on the meaning and the use of משיח in the Old Testament, I have already dealt with one reason for this position: the fact that in the Old Testament משיח was not used for a future salvation figure. I agree with the observation, but the conclusion derived from this observation confuses word and concept.

But there is a second reason why people want to find the origin of messianic expectations in this so-called Second Temple period, and that is the conviction that the experience of the absence of a king in Jerusalem after the exile was the occasion for the emergence of messianic expectations. The understanding is that the failure of the continuation of the Davidic monarchy after the exile led to the projection of the idea of a coming king into the future. What one can agree with in this view is the observation of the formative influence of notions like disappointment and failure in the development of messianic expectations.

However, it has been rightly pointed out by scholars that such notions had already been present at an earlier stage. Already in the period of the monarchy one finds evidence of disappointment and failure. This is most striking in the prophets of the eight century, Amos, Isaiah, and Micah. In their prophecies of judgment they announced the coming of God's judgment over the kings reigning in their own time, and at the same time in a number of their prophecies of salvation (though not in all) they saw a role for a new king, often modelled after David, in spite of the failure of the present occupant of the throne of David and the resulting disappointment. This future king was in many ways an ideal figure who would meet the expectations of peace and justice, which several of the actual kings had failed to meet. It is most probably in this time in which judgment and salvation is announced to the House of David, that one has to find the origins of messianic expectations (see Van der Woude, 1985:102-104). These messianic expectations are rooted in the dynastic oracle of 2 Sam. 7. The promise of God to secure the succession of kings in the Davidic dynasty was the bridge of hope which led people to be convinced that a time in which kings failed miserably or were even completely absent, would not be the last phase in the experience of God's people. 


\section{A special case: messianic expectations in the Books of the Psalms}

There is a number of Psalms in which the figure of the king or the issue of kingship is so prominent that these Psalms are called "royal Psalms". Within this group, there are Psalms in which one finds the word משיח. The king or the "anointed one" mentioned in these Psalms turns out to be not a future king: the poet refers to the present king or addresses the present king. Even the most elevated language, e.g., that the king addresses the LORD as "my Father", or that the LORD calls the king his "first-born", is not restricted to a conversation between God and the future messiah, but can be found in an exchange between God and a historical king, in this case David, as Psalm 89 makes clear.12 When one observes that these Psalms deal with a historical king, and not with a king to be expected, one has to be cautious not to indiscriminately find messianic expectations in such royal Psalms.

I have deliberately called this final part of the article "Messianic expectations in the Books of the Psalms". At a certain moment 150 Psalms were given a place in five volumes which now make up the Psalms as we find them in the Old Testament. One does not know when precisely the redaction of this collection was finished, but it is clear that this must have been somewhere in the period after the return from exile. This was of course a time in which there was no king in Jerusalem.

It is somewhere during this period that these royal Psalms were given a place in the collection of the Five Books of the Psalms. The fact that they were given this place ${ }^{13}$ shows that these royal Psalms were not considered to be entirely useless in a completely different political situation. A number of scholars maintain that the royal Psalms were not made part of the Books of the Psalms out of pure nostalgia, or simply as a reminder of a glorious past (Clements, 1996:58; Broyles, 1997:24; Greidanus, 1999:222-223, 244). The royal Psalms were given a place in the new collection not just as witnesses to the past, but also as beacons to give direction to the hopes and expectations of a new king expectations which were raised by the prophets even from the time before the exile. The royal Psalms draw a picture of the king which contains characteristics which go beyond what is common. This was not

12 The predicates can be found in vv. 27.28. That this is about David can be seen from vv. 5.21.36.

13 Some scholars would even go further and argue that a number of royal Psalms were given a strategic position in the Books of the Psalms, e.g. at the borders of some of the Books (see Wilson, 1985:207-208, 209-214; Zenger, 1997:97-99; Janowski, 1998:381420, 404; for a critique of such an analysis, see Day, 1990:111). 
unusual in that period and in that culture, and it has been labelled "court style". But it is not always clear when reality ends and when court style takes over. Anyway, some very big words in the royal Psalms had raised expectations which had never been realised.

In the period after the exile these royal Psalms played a new role in the collection of the Five Books of the Psalms. And now they become part of the picture when one deals with the theme "messianic expectations in the Old Testament" (Childs, 1979:517; for a discussion of a canonical approach of the Books of the Psalms see Waltke, 1981:3-18; Zenger, 1991:397-413).

\section{- Psalm 72}

To make this more clear Psalm 72 will be presented as an example (Zenger, 1993:57-72; Heim, 1995:223-248). The heading לשלמה allows different interpretations: "by Solomon", or "for Solomon". Some choose the latter option and consider this Psalm to be a prayer of David for his son Solomon (compare Childs, 1979:516-17; Heim, 1995:235). Whether one follows this particular interpretation or not, what is clear is that in Psalm 72 we are dealing with a prayer for a king. Sandwiched between a description of the social conditions (vv. 4-7) of the kingdom and the righteous nature of the rule of the king (vv. 12-14) one finds in vv. 8-11 an outline of the geographical dimensions of the kingdom. These verses may allude to the promise of the land in Exod. 23:31, a section which is part of the conclusion of the Book of the Covenant. When one compares the two descriptions of the borders in these passages, it becomes clear that in Psalm 72 the borders are much wider (Heim, 1995:244-45). What once were the borders of the promised land now become the launch pad for a new setting out of the borders of the kingdom, which now seems to include the world.

Within the context of a prayer for the king one can interpret this as a hyperbole (Heim, 1995:245). The prayer expresses the wish that the area of the kingdom may be as big as the imagination goes. Once the prayer is made part of the collection of the Books of the Psalms, it is given a new context. The prayer is now in a new "environment" some centuries later. There is no longer a king on the throne in Jerusalem. Some of the prophets have prophesied about a new king, who would come after the judgment of the House of David would have been executed. They have raised expectations, ${ }^{14}$ and some of these are messia-

14 Broyles (1997:24), makes a connection between the Messianic prophecies of Isaiah, Micha, Jeremiah, Ezekiel, and Zechariah, and the change of referent in the royal psalms: from the Davidic king to the future Messiah. 
nic expectations. In the new environment of the Books of the Psalms, Psalm 72 now finds a place within these messianic expectations.

One could argue that one finds such a messianic re-interpretation of Psalm 72, or parts of it, already in the Old Testament itself.15 The messianic prophecy of the coming king in Zech. 9:9-10 contains some allusions to features of the portrait of the king of Psalm 72. One of those allusion is that of a kingdom which spans the whole world. In Zech. 9:10 one finds an almost verbatim quotation of Ps. 72:8. On the basis of the syntactical construction one can say that what once was a prayer or wish 16 now has become a prophetic prediction 17: "His rule will extend from sea to sea $[/]$ and from the river to the ends of the earth".

\section{- Epilogue}

The way Zech. 9:10 deals with Ps. $72: 8$ by providing a messianic reinterpretation of an earlier part of the Old Testament, shows that the New Testament does not do something outrageously innovative when it reinterprets parts of the Old Testament in a messianic way and applies them to Jesus. The roots of that way of interpretation can already be seen in the Old Testament itself. But that would be material for yet another chapter in a book about The Old Testament seen in the light of Jesus Christ: Old Testament passages which are re-interpreted in a messianic way in the New Testament.

\section{Bibliography}

BROYLES, Craig C. 1997. The Redeeming King: Psalm 72's Contribution to the Messianic Ideal. (In Evans, Craig A. \& Flint, Peter W., eds. Eschatology, Messianism, and the Dead Sea Scrolls (SDSSRL 1). Grand Rapids, Michigan / Cambridge, U.K. : Eerdmans. p. 23-40.)

CAZELLES, Henri. 1978. Le Messie de la Bible: Christologie de l'Ancient Testament (Collection "Jésus et Jésus-Christ" 7). Paris : Desclée de Brouwer.

CHILDS, Brevard S. 1979. Introduction to the Old Testament as Scripture. Philadelphia : Fortress.

CLEMENTS, R.E. 1996. Old Testament Prophecy. From Oracles to Canon. Louisville, Kentucky : Westminster John Knox Press.

DASSMANN, Ernst \& STEMBERGER, Günther, eds. 1993. Der Messias (JBTh 8). Neukirchen-Vluyn : Neukirchener.

DAY, John. 1990. Psalms (OTG). Sheffield : Sheffield Academic Press.

15 For the Messianic re-interpretation of Psalm 72 in one of the earliest Greek translations of the Old Testament, the Septuagint, see Zenger (1993:61); Heim (995:238-243).

16 Compare the short yiQtol-form (iussive) וירד in Ps. 72:8.

17 Compare Larkin (1994:5). The end of v. 10 is a nominal clause, but the verbal forms in the preceding clauses are weQataltí-forms (Consecutive Perfect), that is, they are not (as in Psalm 72) forms to express a wish. 
DAY, John, ed. 1998. King and Messiah in Israel and the Ancient Near East. Proceedings of the Oxford Old Testament Seminar (JSOTS 270). Sheffield : Sheffield Academic Press.

GOLDINGAY, J. 1984. God's Prophet, God's Servant. A Study in Jeremiah and Isaiah 40-55. Exeter : Paternoster.

GOSLINGA, C.J. 1968. Het eerste boek Samuël (COT). Kampen : Kok.

GREIDANUS, Sidney. 1999. Preaching Christ from the Old Testament. A Contemporary Hermeneutical Method. Grand Rapids, Michigan / Cambridge, U.K. : Eerdmans.

HEIM, Knut M. 1995. The Perfect King of Psalm 72. (In Satterthwaite, Philip E., Hess, Richard S. \& Wenham, Gordon J., eds. The Lord's Anointed. Interpretation of Old Testament Messianic Texts (THS). Carlisle : Paternoster; Grand Rapids, Michigan : Baker Books. p. 223-248.)

HORBURY, William. 1998. Jewish Messianism and the Cult of Christ. London : SCM. JANOWSKI, Bernd. 1998. Die "Kleine Biblia". Zur Bedeutung der Psalmen für eine Theologie des Alten Testaments. (In Zenger, Erich, ed. Der Psalter in Judentum und Christentum (HBS 18). Freiburg Im Breisgau : Herder. p. 381-420.)

KNEVEL, A.G. \& PAUL, M.J., eds. 1995. Verkenningen in de oudtestamentische messiasverwachting (Theologische verkenningen. Bijbel en exegese 8). Kampen : Kok; Hilversum : Evangelische Omroep.

LAATO, Antti. 1997. A Star Is Rising. The Historical Development of the Old Testament Royal Ideology and the Rise of the Jewish Messianic Expectations (University of South Florida International Studies in Formative Christianity and Judaism 5). Ann Arbor: Scholars Press.

LARKIN, Katrina J.A. 1994. The Eschatology of Second Zechariah. A Study of the Formation of a Mantological Wisdom Anthology (CBET 6). Kampen : Kok Pharos.

LETTINGA, J.P. 1980. Hanna's Magnificat. (In Almanak FQI. Kampen : FQI. p. 8995.)

LETTINGA, J.P. 1998. Verzamelde opstellen. Kampen : Publicatiecommissie FQI.

PEELS, H.G.L. 1995. 2 Samuël 7: een fundamentele profetie. (In Knevel, A.G. \& Paul, M.J., reds. Verkenningen in de oudtestamentische messiasverwachting (Theologische verkenningen. Bijbel en exegese 8). Kampen : Kok; Hilversum : Evangelische Omroep. p. 42-50.)

PEELS, H.G.L. 1999a. Eschatologie in het Oude Testament. (In Van 't Spijker, W. et al,, red. Eschatologie. Handboek over de christelijke toekomstverwachting. Kampen : De Groot Goudriaan. p. 9-50.)

PEELS, H.G.L. 1999b. Heiligheid en heiliging in de oudtestamentische eschatologie. (In Van den Boogert, C.J. \& Den Hertog, G.C., reds. Hedendaagse zoektocht naar heiligheid. Aspecten van heiligheid in de bijbel en in de joodse en christelijke traditie. Zoetermeer : Boekencentrum. p. 35-51.)

SATTERTHWAITE, Philip E., HESS, Richard S. \& WENHAM, Gordon J., eds. 1995. The Lord's Anointed. Interpretation of Old Testament Messianic Texts (THS). Carlisle : Paternoster; Grand Rapids, Michigan : Baker Books.

SCHIBLER, Daniel. 1995. Messianism and Messianic Prophecy in Isaiah 1-12 and 28-33. (In Satterthwaite, Philip E., Hess, Richard S. \& Wenham, Gordon J., eds. The Lord's Anointed. Interpretation of Old Testament Messianic Texts (THS). Carlisle : Paternoster; Grand Rapids, Michigan : Baker Books. pp. 87-104.)

STRUPPE, Ursula, red. 1989. Studien zum Messiasbild im Alten Testament (SBA 6). Stuttgart: Katholisches Bibelwerk. 
VAN DER WOUDE, A.S. 1985. Profeet en establishment. Een verklaring van het boek Micha. Kampen : Kok.

VAN GRONINGEN, G. 1990. Messianic Revelation in the Old Testament. Grand Rapids, MI : Baker.

VANGEMEREN, Willem A. 1988. The Progress of Redemption: The Story of Salvation from Creation to the New Jerusalem. Grand Rapids, Michigan : Zondervan.

VIBERG, Åke. 1992. Symbols of Law. A Contextual Analysis of Legal Symbolic Acts in the Old Testament (CBOTS 34). Stockholm : Almquist \& Wiksell International.

WALTKE, B.K. 1981. A Canonical Process Approach to the Psalms. (In Feinberg, J.S. \& Feinberg, P.D., eds. Tradition and Testament. Chicago : Moody. p. 3-18.)

WEINFELD, Moshe. 1995. Social Justice in Ancient Israel and in the Ancient Near East. Jerusalem, The Hebrew University : The Magnes Press; Minneapolis : Fortress.

WESTERMANN, Claus. 1964. The Way of Promise through the Old Testament. (In Anderson, Gary A., ed. The Old Testament and Christian Faith. Essays by Rudolph Bultmann and Others. London : SCM. p. 200-224.)

WESTERMANN, Claus. 1974. Forschung am Alten Testament. Gesammelte Studien Band II (THB). München : Kaiser.

WILLIAMSON, H.G.M. 1998. Variations on a Theme. King, Messiah and Servant in the Book of Isaiah. The Didsbury Lectures 1997. Carlisle : Paternoster.

WILSON, Gerald Henry. 1985. The Editing of the Hebrew Psalter (SBLDS 76). Chico, CA : Scholars Press.

ZENGER, Erich. 1991. Was wird anders bei kanonischer Psalmenauslegung. (In Reiterer, Friedrich V. Ein Gott Eine Offenbarung. Beiträge zur biblischen Exegese, Theologie und Spiritualität. Festschrift für Notker Füglister OSB zum 60. Geburtstag. Würzburg : Echter. p. 397-413.)

ZENGER, Erich. 1993. "So betete David für seinen Sohn Salomo und für den König Messias". Überlegungen zur holistischen und kanonischen Lektüre des 72. Psalms. (In Dassmann, Ernst \& Stemberger, Günther, eds. Der Messias (JBTh 8). Neukirchen-Vluyn : Neukirchener. p. 57-72.)

ZENGER, Erich. 1997. Der jüdische Psalter - ein anti-imperiales Buch? (In Albertz, Rainer, ed. Religion und Gesellschaft. Studien zu ihrer Wechselbeziehung in den Kulturen des Antiken Vorderen Orients. Veröffentlichungen der Arbeitskreises zur Erforschung der Religions- und Kulturgeschichte des Antiken Vorderen Orients (AZERKAVO). Band 1 (AOAT 248). Münster : Ugarit-Verlag. p. 95-108.)

\section{Keywords:}

eight century prophets

Messiah; prophecies of the

messianic expections

New Testament interpretation of the Old Testament

\section{Kernbegrippe:}

agtste-eeuse profete

Messiaanse verwagtings

Messias: profesieë oor

Nuwe-Testamentiese interpretasies van die Ou Testament 